\title{
8 Local Institutions for Wetland Management in Ethiopia: Sustainability and State Intervention
}

\author{
Alan B. Dixon ${ }^{1}$ and Adrian P. Wood ${ }^{2}$ \\ ${ }^{1}$ Department of Geography, University of Otago, Dunedin, New Zealand; \\ e-mail: alan.dixon@geography.otago.ac.nz; ${ }^{2}$ Centre for Wetlands, Environment and \\ Livelihoods, University of Huddersfield, Huddersfield, UK; \\ e-mail: a.p.wood@hud.ac.uk
}

\begin{abstract}
Locally developed institutions that include rules and regulations, common values and mechanisms of conflict resolution are increasingly regarded as adaptive solutions to resource management problems at the grass-roots level. Since they are rooted in community social capital rather than in external, top-down decision making, they are seen as being dynamic, flexible and responsive to societal and environmental change and, as such, they promote sustainability. Within this context, this chapter examines the case of local institutions for wetland management in western Ethiopia. It discusses how the structure and functioning of these institutions have evolved in response to a changing external environment, and the extent to which this has facilitated the sustainable use of wetlands. It is suggested that these local institutions do play a key role in regulating wetland use, yet they have, uncharacteristically, always relied on external intervention to maintain their local legitimacy. Now there are concerns that the institutional arrangements are breaking down due to a lack of support from local administrative structures and current political ideology. This has major implications for the sustainable use of wetland resources and food security throughout the region.

Keywords: community, local, institutions, natural resources management, social capital, sustainability, wetlands, state, Ethiopia.
\end{abstract}

\section{Wetlands, Local Institutions and Sustainability}

Wetlands are becoming increasingly recognized as important natural resources in developing countries because of their ability to fulfil a range of environmental functions and produce a number of products that are socially and economically beneficial to local communities (Dugan, 1990; Silvius et al., 2000). Wetlands act as sponges during dry periods of the year; they regulate run-off and recharge groundwater resources, and they purify water supplies. Their capacity to store water means they are able to support livelihood strategies, such as fishing, pastoralism and agriculture, as well as providing craft materials, clean drinking water and medicinal plants. People's long association with wetlands means that indigenous systems of wetland management and utilization are to be found throughout the developing world.

In recent years, however, much attention has been focused on the need for the "wise use of wetlands' in the context of an increase in 
wetland exploitation and development, fuelled by socio-economic, political and environmental change. In many parts of Africa in particular, agricultural use of wetlands has increased as more and more people have been forced to seek new livelihood strategies, as a result of environmental degradation of other farmlands and population pressure. Government policies that have failed to recognize the significance of local wetland management practices, and indeed the wider value of wetlands, have also stimulated the intensification of wetland agriculture, in an attempt to create more economically productive land. Consequently, a key concern in the long term is that the carrying capacity of wetlands, in terms of the exploitation of products and functions, will be exceeded, resulting in degradation and loss of livelihood benefits for all.

Whilst a Malthusian perspective would argue that such degradation is unavoidable, alternative perspectives in recent years have drawn attention to the ability of local people themselves to adapt their natural resources management (NRM) systems to changes taking place, enabling resources use to remain sustainable (Boserup, 1965; Tiffen et al., 1994). At the core of this adaptive capacity is social capital; commonly interpreted as the shared norms and values, knowledge, institutions and networks intrinsic to a specific community (Pretty and Ward, 2001). Social capital includes the processes of communication and innovation, mechanisms through which new knowledge and practices evolve and which facilitate adaptation. Social capital also constitutes the space in which community-based 'traditional' or 'local' institutions exist (Shivakumar, 2003).

Such institutions, particularly those concerned with NRM, provide the rules and regulations for resources exploitation; they are effective in mobilizing human resources; they are involved in conflict resolution; and, perhaps fundamentally, they have been linked to equitable and sustainable NRM (Uphoff, 1992; Blunt and Warren, 1996; Manig, 1999; Hulme and Woodhouse, 2000). Uphoff (1992) in particular, suggests that local institutions may be particularly successful in NRM where the resources in question are known and predictable, rather than shifting and variable, and where the users are an identifiable group.
Many wetlands in developing countries clearly fit these criteria, in that they usually have a discrete community depending upon their various products and services. Hence, it could be argued that local institutions potentially have a key role to play in facilitating the adaptive and sustainable management of wetlands throughout the developing world.

Mazzucato and Niemeijer (2002) propose local institutions as the 'missing link' in development and adaptation at the people-environment interface. They are regarded as Boserupian adaptations to resource depletion and, through the networks, knowledge, rules and social cohesion associated with them, they mediate people's relationship with the environment (Leach et al., 1999; Manig, 1999; Mazzucato and Niemeijer, 2002). Their overall effect can lead to adjustment and adaptation rather than to environmental degradation and, hence, they can be facilitators of sustainable NRM. Their strength, according to Shivakumar (2003), lies in their indigenous nature, in that they represent 'home-grown' solutions to problems, based on collective understanding. Since they are based on indigenous knowledge, and rooted in social capital that has evolved over generations in a specific culture or environment, they are often regarded by local communities as having greater credibility and legitimacy than external institutions.

As empirical evidence of a relationship between local institutions and sustainable community- based natural resources management (CBNRM) has emerged (Ostrom, 1990; Blunt and Warren, 1996; Hinchcliffe et al., 1999; Pretty and Ward, 2001; Mazzucato and Niemeijer, 2002), so has interest among development practitioners. In an era when rural development and CBNRM have been dominated by the ideals of participation, local institutions have often been regarded as potential short cuts to development; they represent ready-made power structures through which policies can be formed and development initiatives implemented, and they have been taken as models for grass-roots development which can be replicated elsewhere (Warren et al., 1995; Blunt and Warren, 1996; Howes, 1997; Koku and Gustafson, 2001; Guri, 2003; Watson, 2003). The empowerment of local institutions has become a key policy objective, not only in CBNRM projects but also in the 
context of a shifting focus on development issues such as governance, decentralization and civil society.

One critical area of debate, however, centres on the extent to which local institutions themselves are sustainable: whether they can continue to function and support sustainable NRM strategies in the context of rapid change or, in the case of the above, increased intervention from external institutions. At best, such intervention may involve a participatory NGO seeking to empower community relations and the functioning of the institution, whilst in the worst case scenario, intervention may be government driven, top-down and prescriptive in nature, seeking to replace such institutions with state structures.

Watson (2003) describes the failure of NGOs to facilitate sustainable livelihoods, through establishing local, indigenous-based NRM institutions in Borana, Ethiopia. By underestimating both the complexity of resources use and the power relations within the indigenous Gadaa system, NGO intervention has resulted in a perceived devaluing of the existing institutions among their members. Government intervention in the operations of local institutions, meanwhile, has also been recognized as a threat to their legitimacy, credibility and effectiveness (Richards, 1997; Serra, 2001, unpublished), although much depends upon the nature and extent of the intervention, and the resources in question.

One of the enabling conditions for the sustainability of common-pool resource institutions, cited in a review by Agrawal (2001, p. 1659), is that 'the government should not undermine local authority in the functioning of local institutions' (although 'supportive external sanctioning institutions' are considered a prerequisite). Moreover, Rasmussen and Meinzen-Dick (1995) cite the work of Wade (1988), Ostrom (1990) and Bardhan (1993) in arguing that local institutions become more effective when arrangements in the external environment support them. Certainly, the intervention of external institutions may seem justified if, as Manig (1999) argues, local institutions, left to their own devices, may struggle to adapt to rapid socio-economic, environmental or political change.

This external-local institution nexus is implicitly addressed in this chapter, which examines the relationship between local wetland management institutions and the sustainability of wetland use in western Ethiopia. Critically, it explores how these local institutions have evolved in response to environmental, socioeconomic and political change during the last 150 years, and assesses the implications of external intervention in their operations, for their current and future sustainability.

\section{People and Wetlands in Western Ethiopia}

\section{The people}

The ethnic composition of Ethiopia's western highlands is diverse. In Illubabor and Western Wellega zones (see Fig. 8.1) the dominant ethnic group is the Oromo, who account for between 80 and $90 \%$ of the population. Some claim that the Oromo are not, however, indigenous to the area; a period of Oromo migration and expansion displaced and incorporated indigenous Omotic and Sudanic hunter-gatherer and agro-pastoralist groups, who subsequently migrated to lowland areas.

The second largest ethnic group is the Amharas (approximately 10\%) who, during the late 19th century and under the leadership of Menelik II, expanded their empire to the south and the west of what was then the 'Abyssinian Kingdom'. Through this conquest and a continuous process of inward migration and resettlement, the lands of present-day Illubabor and Western Wellega were subsequently annexed into what became the modern Ethiopian state by the end of the 1890s. The remainder of the population is, as a consequence of migration, immigration and government resettlement schemes during the 1970s and 1980s, composed of Tigrayan and Gurages from the north and east of the study area, and Mocha and Keffa peoples from the immediate south, with small numbers of other ethnic groups from around the country.

\section{Wetlands}

Wetlands are a common feature of the landscape in the highlands of western Ethiopia, particularly Western Wellega and Illubabor. The warm, temperate climate, characterized by a 


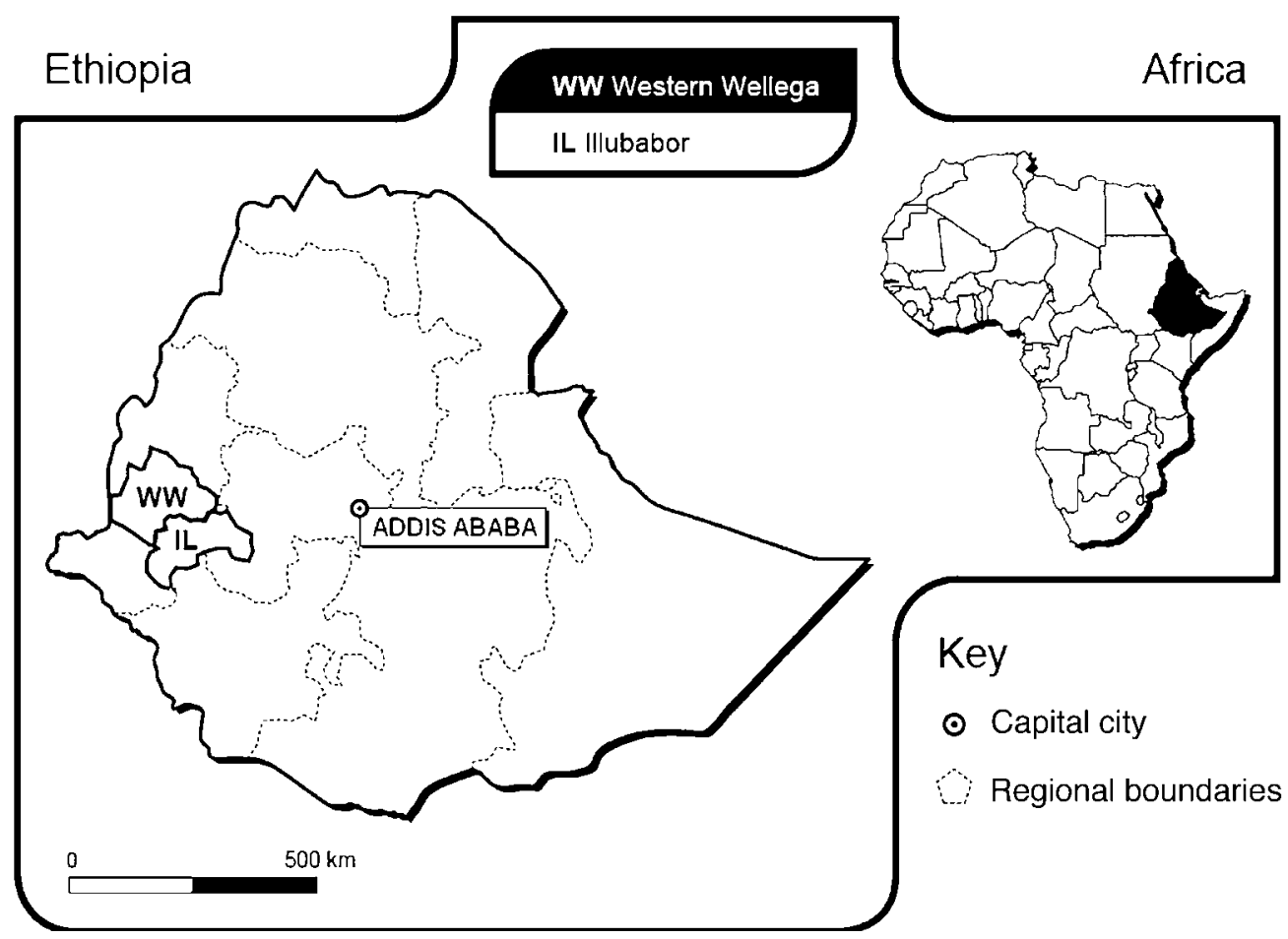

Fig. 8.1. Map of Ehiopia.

mean annual temperature of around $20^{\circ} \mathrm{C}$ and annual rainfall usually in excess of $1500 \mathrm{~mm}$, together with the undulating to dissected topography, which ranges between 1000 and $2000 \mathrm{~m}$ above sea level, produce an environment characterized by steep-sided river valleys and flat, waterlogged valley bottoms. The accumulation of run-off, poor drainage and a high groundwater table in these valley bottoms promotes the formation of both permanent and seasonal swamp-like wetlands, ranging from < 10 to $>300$ ha (Dixon, 2003). It has been estimated that approximately $4 \%$ of Illubabor's land area is occupied by wetlands, and this proportion is likely to be similar for Western Wellega, to the north (Afework Hailu, 1998, unpublished).

The wetlands are vital natural resources, both in terms of their environmental functions and their products, which are used extensively by local communities. They represent a vital source of water throughout the year, in an area which receives half of its annual rainfall between June and August, and only $5 \%$ during the dry season months of December, January and February. The storage and release of water from the wetlands and their peripheral springs ensure that local communities have access to clean drinking water throughout the year. The abundance of water in the wetlands also supports the growth of dense sedge vegetation known locally as cheffe (Cyperus latifolius) which, in addition to providing limited fodder for cattle, is traditionally harvested by local communities for use as a roofing and craft material. It is also used throughout the year in a range of ceremonies and celebrations and, as such, it is a marketable commodity. The wetlands are also a habitat for a variety of other plant communities, some of which are used for medicinal purposes by those living around the wetlands. For example, the plant known locally as balawarante (Hygrophila auriculata) is used as a treatment for various skin diseases (Zerihun Woldu, 1998, unpublished).

As reservoirs of soil moisture during dry periods, these wetlands are also valuable agricultural resources and many have traditionally been used, albeit on a small, informal scale, to 
cultivate maize much earlier in the agricultural calendar than on the uplands (Tafesse Asres, 1996; Wood, 1996). This practice, which includes the majority of the wetland maize crop being harvested before maturation, i.e. during its 'green' phase, facilitates the production of crops during a period of the year which is normally associated with food shortages.

Over the last century, however, it appears that wetland cultivation has extended beyond the use of wetland margins to include much larger areas, and nowadays the complete drainage and cultivation of wetlands are common phenomena throughout the region. Recent estimates have suggested that wetland cultivation provides somewhere between 10 and $20 \%$ of the annual food needs of the region's population (Ethiopia Network on Food Security, 2001) but, during the food shortage months, its contribution rises to $100 \%$ in some areas. In Western Wellega, in particular, the dependence on wetlands for food security is greater than that in Illubabor, and it appears that more intensive forms of wetland cultivation have existed over a longer period of time. This appears to be a product of population pressure in Western Wellega and the conspicuous degradation of upland farming areas. In contrast, Illubabor has less population pressure and the uplands have remained relatively fertile, in part because of the abundance of forests.

The current system of wetland drainage and cultivation is dominated by the cultivation of maize, although in some areas sugarcane, tef (Eragrostis tef) and vegetables, including cabbage and potato, are also grown in small quantities from year to year. The wetland agricultural calendar typically begins after the rains subside, usually in September or October, when some farmers may cultivate tef on the residual moisture. It is more common, however, for cultivation to begin with the sowing of a maize crop sometime between January and March. Prior to this, existing drainage channels are cleared of weeds or cheffe, or new channels are excavated - usually in a herringbone pattern - to ensure appropriate soil moisture conditions for the water-intolerant maize crop. The maintenance of drainage channels and the guarding of the crop against wild pests continue throughout the year until harvesting, which usually occurs during the start of the rains (between June and July).
Wetlands tend to be divided among numerous farmers from the local community. The allocation of wetland plots in some instances dates back to the early 20th century (see below), with the number of stakeholders depending upon the size of the wetland and the demand for agricultural land within each community. It is common for wetlands of 40 ha in size to have over 300 local cultivators (Afework Hailu et al., 2000, unpublished). Given the large number of stakeholders involved and the dynamic nature of the wetland environment, the whole system of wetland management requires a significant amount of coordination in terms of farming resources and manpower.

\section{The origins of and changes in wetland cultivation}

Although there are conflicting accounts of the origins of wetland cultivation in the area, it is generally agreed that more intensive forms of wetland cultivation were initiated in response to food shortages on the uplands caused by drought in the early years of the 20th century. During this period, land was effectively owned by a few feudal landlords, and installed by the expanding Amhara Empire in the late 19th century, who rented out their lands to peasant farmers. With the occurrence of drought and food shortages, many landlords either instructed their peasant farmers, or granted a request from farmers themselves, to cultivate wetlands in order to achieve food security. Following an initial period of trial and error, during which farmers experimented with different management practices with varying degrees of success, wetland cultivation became the mainstream agricultural activity in many areas.

With the overthrow of the Haile Selassie government by the Derg in 1974, the social dynamics of wetland use changed. In 1975, the Derg nationalized all rural land, with the result that wetland access was controlled by the newly established kebeles (peasant associations) that constitute the lowest administrative unit of the government. In most cases, however, those who previously had access to wetland plots were, on request, given custodianship over the same plots. 
Wetland agriculture during the Derg period (1974-1991) was characterized by an increase throughout the region for several reasons. First, wetland cultivation was encouraged by the government in order to meet regional targets of food self-sufficiency. Failure to cultivate in accordance with this policy risked the reallocation of wetland plots to other farmers who were willing to expand into wetland cultivation (Afework Hailu, 1998, unpublished). Second, the expansion of coffee production in the area, and the wider commercialization of farming in particular, resulted in local shortages of upslope agricultural land and, hence, the cultivation of wetlands became the means of subsistence for some farmers. Finally, in response to the famine of 1984, Illubabor and Western Wellega were chosen by the government as resettlement areas for famine victims. This inward migration of approximately 100,000 people, often to localized areas, resulted in further agricultural land shortages (Alemneh Dejene, 1990) and, in many cases, wetland plots were allocated to settlers (who, unlike the Oromo population, had no experience of farming under such conditions).

The only significant change in wetland agriculture since the change in government in 1991 has been the pressure to cultivate wetlands more intensively. This has stemmed from a government initiative in 1999 which, in response to drought-induced food shortages, sought to establish a Wetlands Task Force in each kebele. Although precise details of the Wetlands Task Force policy are unclear, many kebeles throughout Illubabor and Western Wellega have formed committees specifically to oversee the complete cultivation of wetlands. Ironically, while the implementation of this policy may have an impact on food security in the short term, it arguably represents a major threat to the sustainability of wetland agriculture, since it threatens to override locally adapted management practices and the knowledge base and indigenous organizational activities within local wetland-using communities.

Recent research by the Ethiopian Wetlands Research Programme (EWRP) in Illubabor, undertaken in response to concerns about widespread unsustainable use and wetland degradation, have drawn attention to the important contribution of local knowledge to sustainable wetland management practices. This research reported that few wetlands showed signs of environmental degradation, mainly because of the application of farmers' knowledge and experience. Among other things, farmers have developed extensive knowledge of wetland eco-hydrological process, vegetation changes, different cropping scenarios, drainage layouts and, critically, mechanisms of ensuring sustainability.

One such mechanism involves the practice of retaining areas of cheffe vegetation at the head of each wetland. These areas act as a reservoir of water and ensure there is always enough moisture distributed throughout the wetland to facilitate crop production. Farmers also use various plants as indicators of the 'health' of their wetland. For example, the plant known locally as kemete (leersia hexandra) is considered an indicator of poor fertility, and on its colonization it is common practice to abandon the wetland plot until fertility is restored (indicated by a host of other plants).

Ongoing research in the area has also drawn attention to the importance of local institutions formed specifically to coordinate wetland management activities among the various stakeholders. These institutions have emerged as a key factor influencing wetland sustainability.

\section{Wetland Management Institutions}

\section{Distribution and origins}

Wetland management institutions (WMIs) exist throughout Illubabor and Western Wellega, although their development over time, organizational structure and functions is spatially and temporally variable. They are known locally by a variety of names, including Abba Laga (father/leader of the catchment), Abba Adere (father/leader of a group of villagers), Cheffe Kore (wetland committee) and Garee Misooma (development committee). The name Abba Laga is the most frequently used in conjunction with the WMIs, especially in Western Wellega where wetland cultivation has a longer history than that of Illubabor.

The extent (if any) to which Abba Laga and Abba Adere had played a role in the traditional Oromo Gadaa system of administration prior to 
the Amhara invasion in the late 19th century remains unclear. The Gadaa system of public administration was itself brought to Illubabor and Western Wellega during the Oromo invasion of the area during the 17th and 18th centuries and, although its form and application varied from place to place, it was essentially a traditional socio-political institution in which the male members of each community progressed through different life 'grades', each with its own associated rights and responsibilities.

Within the system, one grade ruled for 8 years, before being replaced by another and, within each 8-year period, an Abba Gadaa (father of power), Abba Dula (father of war) and Abba Sera (father of the law) were elected (Hassen, 1990; Watson, 2003; see Desalegn et al., Chapter 9, this volume). Whilst there is no documented evidence of either Abba Laga or Abba Adere playing an essential role in the Gadaa administration, it is probable that Abba Laga was a title instituted when and where the need to coordinate land use occurred. In the current day Borana zone in southern Ethiopia, where remnants of the Gadaa system still exist, Watson (2003) reports that Abba Konfi (father of the well) regulates access to water, yet there is no indication that the title is intrinsically linked to the Gadaa life grades system.

Eventually, in western Ethiopia, the Gadaa system gradually eroded as a result of local warlords undermining its administrative officials, and the system appears to have disappeared some years before the Amhara conquest. The origins of Abba Laga and Abba Adere are, therefore, ambiguous, and require further investigation. Recent reports from farmers in the area suggest that the titles were simply modifications of previous Gadaa era roles, in response to the need for a new institution in the light of an increase in wetland use during the Haile Selassie era. What appears different to the traditional Gadaa administrative roles, however, is that the title (either Abba Laga or Abba Adere) is now used interchangeably to describe both the institution itself, that is made up of participating farmers, and the appointed head of the institution, rather than just the latter as during the Gadaa era. The Cheffe Kore and Garee Missooma, which are the names used more frequently in Illubabor, tend to be Derg or post-1991 reinventions or reproductions of previous titles of Abba Laga and Abba Adere and, in some instances, there is evidence to suggest that these institutions were actually organized and initiated by the local agents of the Ministry of Agriculture Development.

\section{Role and functions}

Throughout Illubabor and Western Wellega, the role of the WMIs is similar. They are a mechanism through which wetland users, almost exclusively men, ${ }^{1}$ coordinate and facilitate cooperation in all wetland management activities, particularly in the preparation of drainage ditches prior to cultivation. Given the often elaborate design of drainage networks and the large number of stakeholders involved in each wetland, there is a need to ensure that the correct depth and width of all the drains are adequately maintained at roughly the same time, so that the soil moisture conditions are optimal for cultivation. It is usual practice for the elected leader of the institution to decide the date when this and other activities will take place, and ensure that all farmers comply with the decision.

The WMIs are also involved in a range of other activities, including the coordination (or joint work) of farmers for guarding crops, hoeing, weeding, ploughing and sowing, although the general maintenance of crops and harvesting are undertaken on an individual basis. In some areas where water shortages are a recurrent problem during the dry season, the institutions coordinate farmers' access to wetland drain water (for irrigation) via a system of rotation, while they may also plan and coordinate the blocking of drainage ditches to maintain water levels in the wetland, especially at the time of sowing and seed germination. The institution is also involved in mobilizing labour for tasks such as building footpath bridges across wetlands.

In some respects, the WMIs play a role similar to that of other local institutions, particularly Debo and Dado, both indigenous work group organizations, formed whenever needed, for tasks such as forest clearance or harvesting. Dado differs from Debo in that the work arrangement is one of reciprocal labour, i.e. the person requesting the Dado for his land is 
obliged himself to work in Dado for another person. In Debo, the organizer provides food and drink rather than reciprocating work by himself. Both are often utilized for tasks such as ditch clearing and harvesting in the wetlands and, hence, they represent important organizational components of the WMI constitution. They are, however, voluntary organizations, and it is uncommon for all the cultivators of one wetland to belong exclusively to one Dado or Debo arrangement.

One key challenge for the WMI, therefore, is to coordinate the various groups so that an activity such as ditch clearing can be carried out at the same time. Whilst other indigenous institutions such as Tula and Ider also exist, these are associated with social welfare and funeral arrangements. In some cases, they are influential in mobilizing labour for wetland activities if one member of the WMI or wider community is sick, imprisoned or absent. They also provide a forum in which information on wetland management is communicated (Dixon, 2005) but, in general, they are regarded as having little to do with wetland management activities or the enforcement of the WMI constitution.

A key function of the WMIs, which differentiates them from these other local institutions, is their role in controlling potentially destructive agricultural practices, such as excessive cattle grazing, which leads to the compaction and erosion of soil in wetlands. Similarly, some institutions restrict wetland cultivation to only one crop per year, whilst also prohibiting the cultivation of tef, sugarcane or the increasingly ubiquitous eucalyptus that are damaging in terms of their soil moisture requirements:

Some people like to plant potato and tef after the maize is harvested, but so far no one has planted eucalyptus trees on the wetland we are cultivating. If someone wants to, the committee will stop it. Usually following the maize harvest the wetland is fenced. Drainage ditches are blocked and the land is allowed to flood.

(Farmer at the Hadesa Wetland, Illubabor, 6 March 2003)

WMIs make informed decisions on whether whole wetlands should be used for cultivation, reserved for cheffe production or whether the wetland is perceived as being degraded, abandoned and left to regenerate.
In order to function successfully, the institutions require all its members to cooperate and abide by a series of rules and regulations, which are either informally agreed upon or, in some cases, written in a constitution (see Fig. 8.2). If the latter is the case, each member is required to sign the constitution, which usually also states that the failure of a member to comply with the rules is punishable by either a fine or imprisonment. This, according to farmers, seldom happens in practice, since most conflicts are settled amicably by those involved. This process of conflict resolution, the stakeholders involved, constituent membership and the organizational structure of the WMIs appear to have evolved as the experience of wetland management has grown and the wetland environment itself has changed as a result of human interventions. Successive changes of governments have also played a key role in shaping these institutions, albeit indirectly through local adaptive responses to political and socioeconomic change.

\section{Historical changes}

During the Haile Selassie era (1930-1974), it was common practice for either the landlord to appoint an Abba Laga leader to set up a WMI (which would be known by the same name) and coordinate wetland cultivation in each wetland, or for farmers themselves to propose an Abba Laga. In those cases where landlords owned numerous wetlands, a Teteri (landlord's representative) was appointed to oversee the local Abba Laga (see Fig. 8.3). In compensation for their wetland management duties, the taxes of each appointed Abba Laga leader would be waived. Any problems arising in the wetland were first reported to the Abba Laga leader, then to a Teteri if present and, finally, to the landlord himself (if present, since many were absentees). The final decision on whether to cultivate the wetlands ultimately rested with the landlord.

Land nationalization during the Derg era (1974-1991) brought about the redistribution of wetland plots, largely on the basis of family size and, with no landlords present, the organization and election of WMIs - which occurred then for the first time in some communities - 


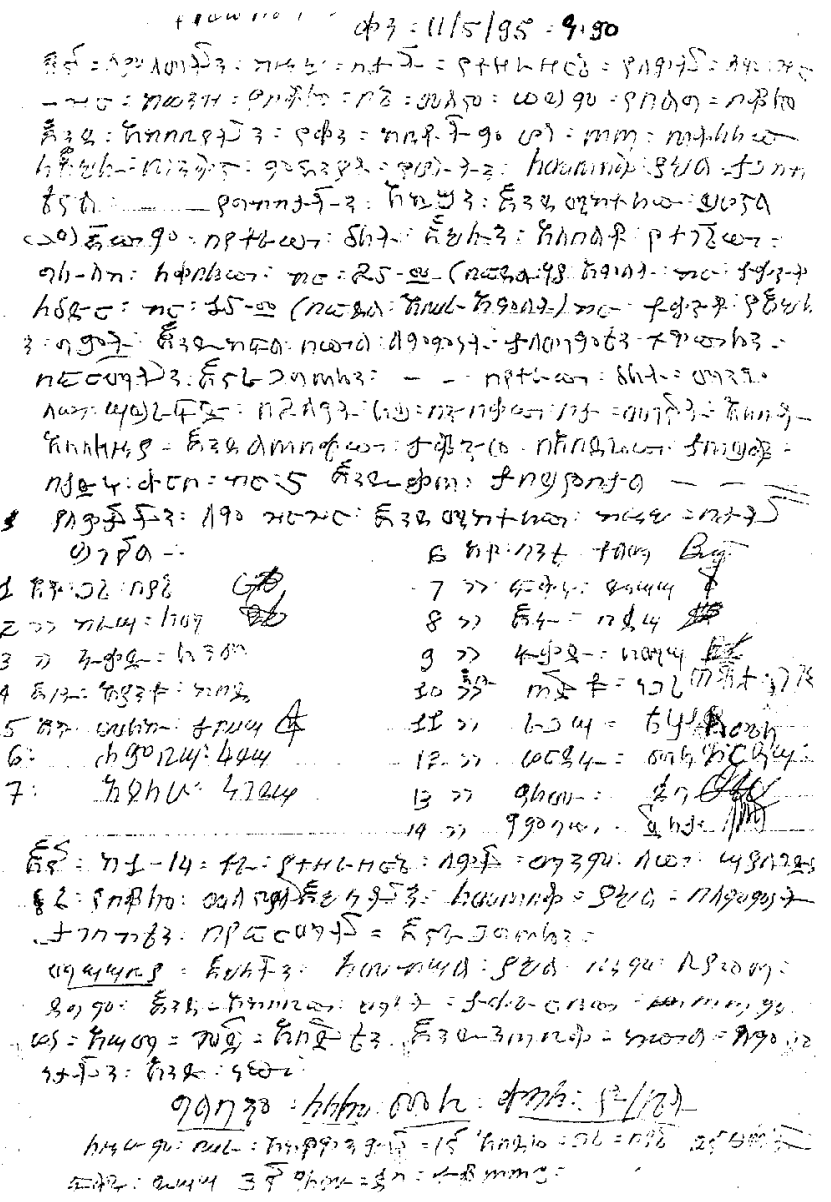

Date: 19th January, 2003

We, the users of Gafare Abba Mati wetland have agreed to cooperate with each other in wetland agriculture according to our local calendar.

The following are our terms of agreement:

- We have agreed to guard wetland crops against wildlife and livestock turn by turn.

- Anyone who fails to properly guard crops on his turn and as a result of which wetland crops may be damaged, will be penalized 25 Ethiopian birr to the kebele administration, 10 birr to the Ider, and pay the estimated amount of crop damaged to the owner of the crop.

- When the crop is mature, every neighbourhood should construct huts and is expected to guard the crop regularly against wildlife damage in the evening

- Every individual on his turn is expected to visit the field without waiting for orders from coordinators, at 8:00 am, and he should properly guard the crop the whole day. If he fails to do so, his case will be investigated by the Ider and if found guilty he will be penalized 5 birr.

- The following three pecple are elected as the management committee Ambaw Jaleta - Abba Adere /Chairman

Fikadu Disasa - Secretary

Alemu Daba - Inspector

- The names of the signatories of this agreement are listed below:
1. Gari Bevene
5. Melku Tasisa
9. Benti Tesema
2. Birrisa Lemma
6. Hambisa Fayissa
9. Benti Tesema
10. Fikiru Disasa
13. Tajitu Nagari
3. Fikadu Lencho
7. Ayalew Rudsa
11. Ifa Bedasa
14. Reggasa Tesso
4. Ayantu Kebede
8. Alemu Daba
12. Fikadu Lamessa
15. Hordofa Chala

We whose names are listed above have agreed to be governed by the rules mentioned and have approved it with our signature without any external pressure.

$\mathrm{Cc}$

To Lalo Chole kebele administration office

Fig. 8.2. Example of a written constitution. 


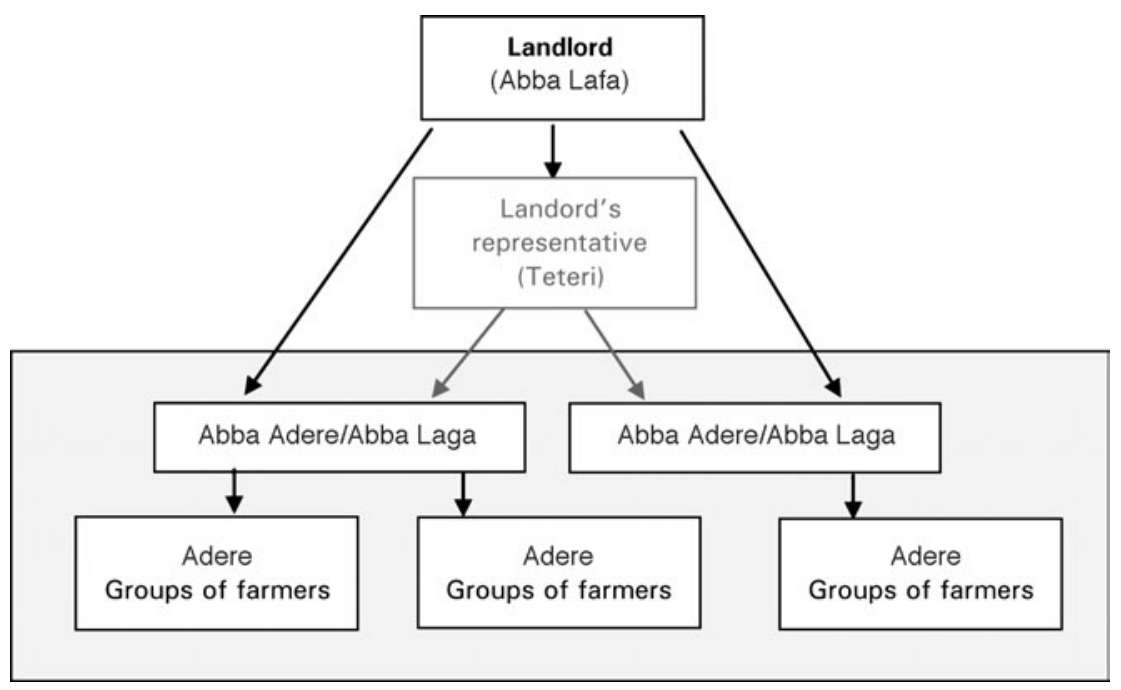

Fig. 8.3. A typical WMI structure during the Haile Selassie era.

were placed in the hands of the wetland users themselves. In many respects, these traditional labour and management associations complemented the new government's ethos of locallevel cooperation and, indeed, evidence suggests that some of the WMIs formed in this era originated as farmer cooperatives:

The wetland management committee was established here in 1982 when we first started to fully cultivate the wetland. The idea came from the woreda [district] agriculture office. They passed instructions to all kebeles to drain and cultivate wetlands, and they suggested that we organize ourselves to cultivate in a coordinated manner. Then we discussed it among ourselves, started draining the wetland and established the management committee.

(Farmer at the Shenkora Wetland, West Wellega, 31 January 2003)

The newly formed kebeles (neighbourhood cooperatives and the smallest units of government), however, were assigned ultimate responsibility for overseeing the functioning of the WMIs, although the nature of their influence varied from location to location. Whilst the kebele played a key role as decision maker in wetland cultivation activities in some areas, in others its function was solely one of last resort for conflict resolution. In the opinion of most farmers, the kebele-wetland institution relationships formed during this era were the most productive in terms of efficient and successful wetland management, on account of the backstopping (largely enforcement-orientated) role played by the kebele.

The number of members in the leadership of the WMIs also increased during the Derg era and, in some areas up to seven persons, rather than one, are reported to have been elected to the WMI committee by the community of wetland cultivators (see Fig. 8.4). As in the Haile Selassie era, the committee of the WMI was responsible for the day-to-day operations of wetland management, namely coordinating activities and reporting problems. Farmers refusing to abide by the constitution of the WMI (which would have been discussed in an annual or biennial meeting of a Wetland Users Assembly) were then reported by the committee to the kebele administration, who may or may not have referred the matter to the kebele court.

According to farmers, however, conflict between those in the WMI was a rare occurrence during the Derg era on account of the strong punishments imposed:

Even a farmer could be imprisoned for a month and his ownership right could be removed by the wetland committee without any approval from 


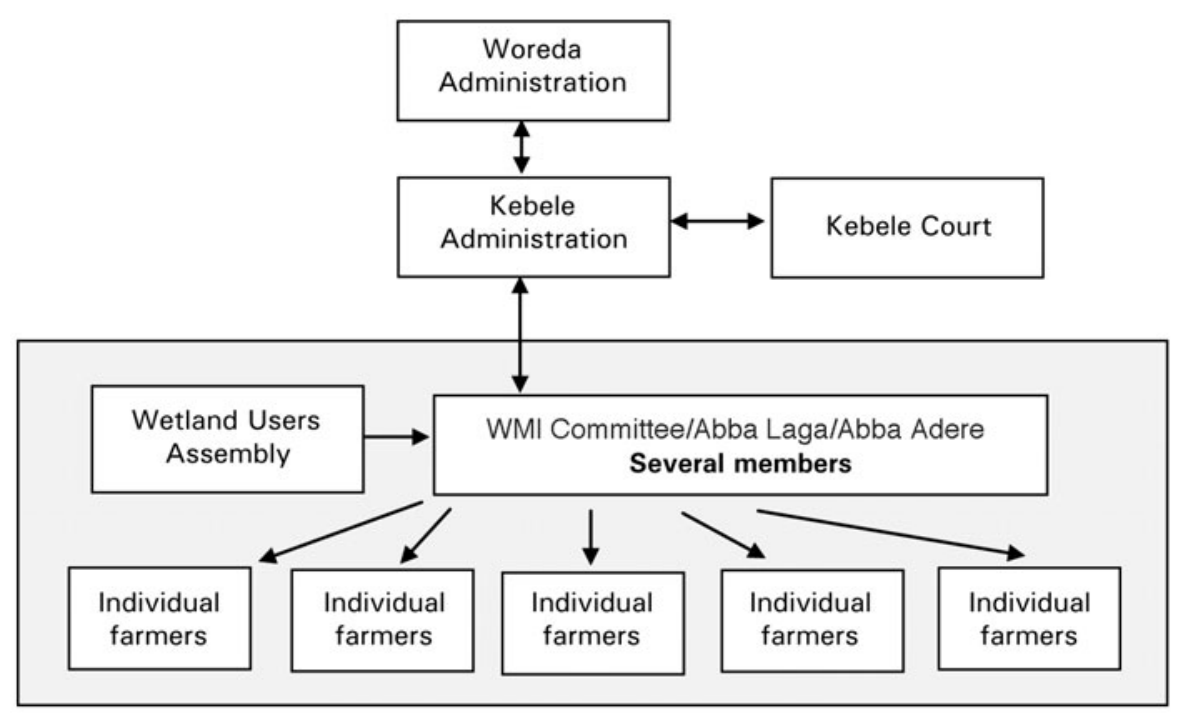

Fig. 8.4. A typical WMI structure during the Derg era.

the kebele administration. With one farmer, his legs and hands were tied with a rope and he was put next to termites for more than two hours to punish him ... because of these practices coordination among wetland users was very strong and the wetland management committee was also very strong and powerful.

(Farmer at the Minie Wetland, Illubabor, 8 February 2003)

The kebele administration was reportedly very active in supporting the WMI and although, like the landlord, it often intervened directly in wetland use issues in a top-down manner, it arguably provided a means of legitimizing the authority of the WMI committee.

The post-Derg era since 1991 has been characterized by further land redistribution and minor structural changes to WMIs (see Fig. 8.5). The federal government's focus on regionalization and decentralization appears to have had both positive and negative impacts. Most WMIs have undergone self-induced structural change to fit in with the new 'democratic' ideals promoted by the government: for example, increasing membership of the WMI committee to make it more transparent and accountable to its members. Many farmers, however, protest that the concept of democracy has been misinterpreted by wetland users who wish to 'exercise their individual democratic right' not to participate in communal activities such as ditch digging or guarding against wild pests.

WMIs have also eroded further, say farmers, through the lack of interest shown by the kebele administration in addressing such problems, and in wetland management generally. The reasons offered by farmers for this lack of kebele support vary from corruption among the kebele committee to a simple lack of available time and resources, in the light of more pressing socio-economic and political concerns. The net result, however, is that most WMIs now exist in a more weakened state than ever before, since their mechanisms of enforcement have been removed. This, potentially, has major implications for the sustainable management of wetlands:

Everyone says, 'it is my right to work or not'. It seems the current democracy given by the government is having a negative role in the area. The kebele administrations don't take any measures against those who refused to cultivate. In summary, the current situation is not conducive to using our wetland properly.

(Farmer at the Korqa Wetland, West Wellega, 30 March 2003) 


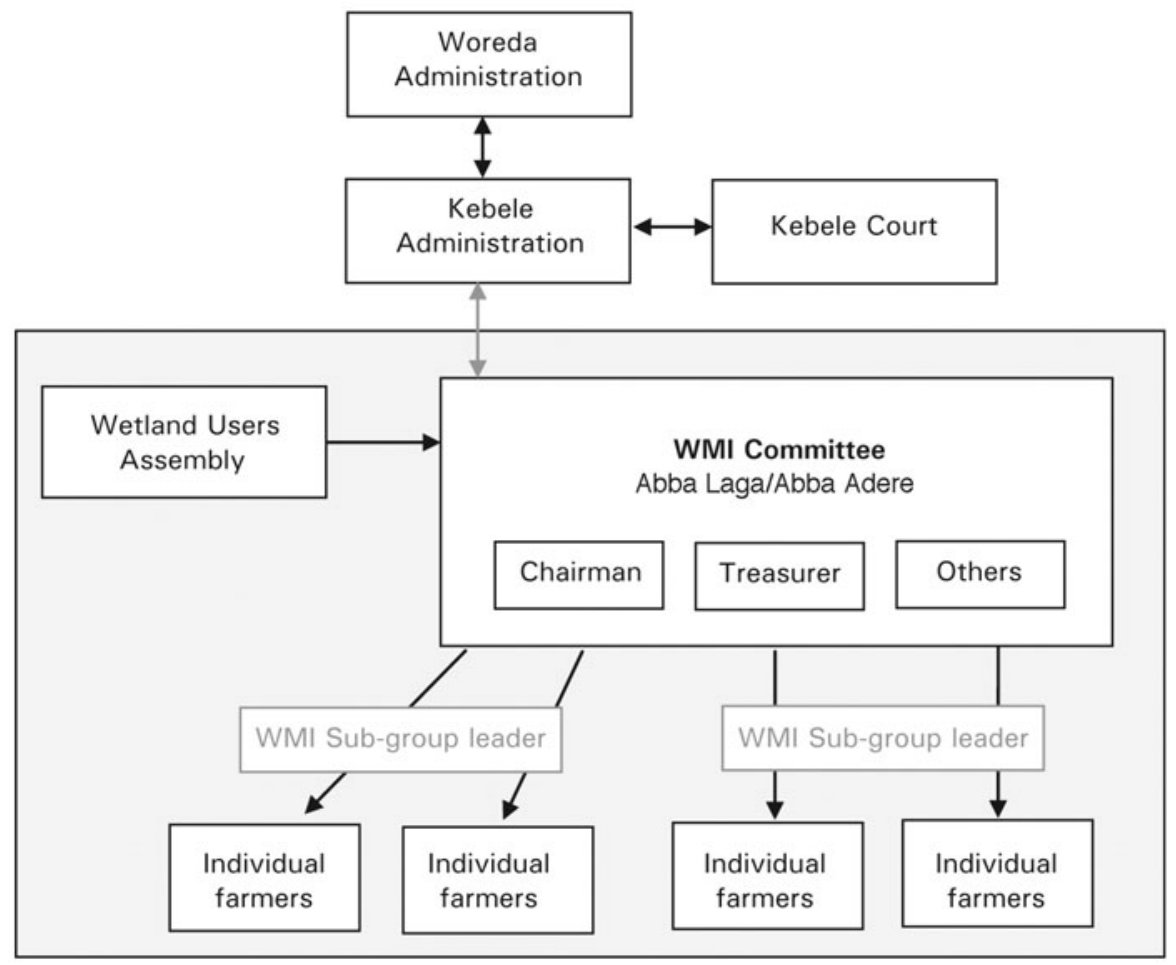

Fig. 8.5. A typical WMI structure in the post-Derg era.

\section{Building Relations with the State: the Key to Wetland Institutional Sustainability?}

What is clear is that a range of institutions external to WMIs have, to varying degrees, influenced their structure and functioning since wetland cultivation first began. In Illubabor, local government institutions such as the Ministry of Agriculture and the kebele and woreda administrations have played a particularly prominent role during the initial establishment of WMIs. Perhaps as a result of this, the WMIs in Illubabor now appear more dependent on the intervention of these external institutions for the enforcement of rules and regulations. Even in Western Wellega, where wetland cultivation has a longer history, and where external state institutions have been less influential in the actual formation of WMIs, farmers now insist that the kebele administration should play a fundamental role in conflict resolution.
Despite their informal linkages with external and indigenous institutions, the extent to which WMIs are recognized as functioning institutions in the wider context of wetland policy making is ambiguous. Some communities evidently work more closely with staff from the Ministry of Agriculture than others and, in some cases, members of the ministry staff assist in organizing meetings for the WMI committee. In such cases, local development agents undoubtedly have some sensitivity to the importance of wetlands and their local management arrangements.

At any level higher than that of the development agent, however, there appears to be no official recognition of WMIs in official agricultural or NRM policy, although members of the ministry staff do personally acknowledge their existence. Given that the majority of WMIs acknowledge the need for external intervention in their decision making, a key challenge exists in terms of raising awareness of the potential importance of WMIs (and arguably other local 
institutions) among external policy-making institutions, and transforming existing knowledge and awareness into real policies that support local-level wetland management.

Given that the functions and structure of the WMIs have much in common with those local organizations cited in much of the literature (Rasmussen and Meinzen-Dick, 1995; Blunt and Warren, 1996; Agrawal, 2001; Mazzucato and Niemeijer, 2002) a key question is: To what extent have they facilitated the sustainable management of wetlands in Illubabor, Western Wellega and possibly elsewhere in Ethiopia?

Whilst most wetland users would agree that crop yields have declined over the years as a result of falling fertility in the wetlands, there is little evidence of widespread wetland degradation characterized by falling water table levels and the inability of wetlands to support agriculture or cheffe production. As suggested earlier, the intimate knowledge and understanding of the wetland environment among wetland users in most cases inform management practices, such as fallowing and ditch-blocking for moisture management, that support sustainable utilization (Dixon, 2003). Furthermore, many wetland farmers are active in small-scale experimentation, seeking solutions to problems and adapting to change.

In examining the relatively few cases of serious wetland degradation, the Ethiopian Wetlands Research Programme drew attention to several potential causal factors. First, where local NGOs or government departments were particularly active in dictating drainage and cultivation regimes, local knowledge and management practices were effectively overridden, and the benefits of wetland agriculture under such scenarios were found to be short-lived (Wood, 1996; Afework Hailu et al., 2000, unpublished).

Secondly, the research highlighted the use of inappropriate practices, such as the excavation of deep drainage channels or the allowing of cattle unlimited access to wetlands, critically, despite recognition from farmers themselves that these practices were destructive. In examining why this might be the case, it was suggested that the lack of cooperation and communication between farmers, often from different kebeles, prevented the formation of institutional arrangements to govern equitable and sustainable wetland use. Similarly, in a recent study of the relationship between communication networks and wetland sustainability (Dixon, 2005), the lack of social capital, in terms of cooperation, communication networks and common values among wetlandusing communities, clearly manifested itself in the form of wetland degradation. In effect, a breakdown in communication, cooperation and mutual respect among wetland users, for reasons which require further investigation, was shown to lead to destructive practices such as overgrazing and double cropping.

It would appear, therefore, that in Illubabor and Western Wellega, the WMIs do make an important contribution to the environmental sustainability of wetlands via the regulation of management practices, their role in conflict resolution and, at the very least, bringing stakeholders together.

There remain, however, inherent problems with wetland management, suggesting that the current system, and indeed the institutions associated with it, lack the capacity to cope with elements of environmental, socio-economic and political change. Hence, there are concerns over the environmental, economic and social sustainability of wetland management, and the sustainability of the WMIs themselves.

The importance of the adaptive capacity of WMIs is illustrated by the concern among farmers that they are increasingly struggling to cope with unprecedented variability in the timing, duration and intensity of the rains, which affect soil moisture, weed growth, the prevalence of insect pests and, ultimately, the economic sustainability of wetland cultivation. Adapting to such changes in weather patterns means adjusting the wetland farming calendar and being flexible and responsive, a logistically difficult task given the communal nature of management and farmers' concurrent interests in the uplands. Clearly, the WMI has a critical role to play in facilitating adaptation to change in such circumstances; yet at the same time the institution appears to struggle with even the more mundane and predictable wetland management issues, such as coordinating farmers to guard against wild pests:

We depend on wetland cultivation for food production but in recent years there have been problems with termites, wild pests and worms.

The problem is getting worse because of a lack of coordination among each other. In the past, Abba Laga was powerful in coordinating farmers but 
today it is powerless to take action against those who break the rules due to a misinterpretation of the new democracy, and lack of support from government. Some farmers abandon the land between plots, so the rodents and other wild animals hide there and attack the crops.

(Farmer at the Korqa Wetland, West Wellega,

30 March 2003)

The above quote reiterates the major problems influencing the effective functioning and sustainability of the WMIs, and the sustainability of wetland use itself at the present time: the loss of respect for the institutions among their membership, and the lack of support provided by the kebele administration. Both, according to farmers, have weakened the capacity of WMIs to coordinate wetland management and enforce what are ultimately reciprocally beneficial rules and regulations.

In response to these problems, farmers are seeking greater external intervention in the functioning of the WMIs. They regard the kebele administration and the associated kebele court as structures that legitimize and backstop the rules and decision-making process that are central to the effective functioning of the WMIs. Many would like to see the kebele playing a role in formulating written constitutions for wetland management, which include enforceable penalties for non-compliance. Others seek greater representation of wetland stakeholders on the kebele committee. If, however, more power were to be handed over to external institutions, this once again raises issues of local institutional legitimacy, effectiveness and sustainability (Ostrom, 1990; Richards, 1997; Serra, 2001, unpublished; Watson, 2003). Moreover, there is a danger that the kebele administration, as a government-biased institution, will encourage the use of wetlands in an unsustainable manner, in pursuit of politically important policies such as short-term regional food security.

With the local government intervening more in the day-to-day operations of the WMIs, one key concern is whether this would erode their flexibility and capacity to operate effectively outside the vagaries of bureaucratic government administrations. One could argue, however, that this erosion is unlikely to occur, since the WMIs of Illubabor and Western Wellega are atypical of the many 'indigenous' local institutions cited in the anthropological literature. They have, in effect, always relied on external intervention in one way or another, whether this was via landlord edicts during the Haile Selassie era or the kebeles who helped establish many WMIs during the Derg era. Moreover, the need for external intervention emanates from the WMI members themselves and, hence, any linkages formed arguably represent 'bottom-up' adaptive responses to the current pressures facing the WMIs.

In addition to seeking increased participation from the kebeles, some WMI members have suggested that they should possess their own legal authority, thereby enabling them to implement penalties without having to refer cases to the kebele committee or court. Accordingly, most communities are in the process of increasing membership of the WMI leadership and establishing more subgroup leaders so that more land inspections can be carried out and conflict resolution dealt with in a more democratic fashion:

To strengthen the committee we want to increase the committee members from five to seven. The addition of committee members is to strengthen the activities of team leaders and proper inspection of the whole wetland system. The wetland management committee also needs to establish a strong constitution which manages the whole wetland system including the catchment. The committee needs to get recognition by government bodies and considered a legal community organization.

(Farmer at the Minie Wetland, Illubabor, 5 March 2003)

In those WMIs where problems exist, it seems most members are well aware of the nature of the problems and potential solutions to these problems. Whilst some have begun to make small-scale changes to their structure and functioning in response to new challenges, many appear powerless to implement changes at the present time, again because of the perceived withdrawal of local administrative support. If this support is provided, however, and WMI members are allowed scope to implement their suggested changes, then the adaptive potential of these institutions could dramatically increase. This would inevitably empower capacity for sustainable wetland management. 


\section{Conclusions}

The local WMIs found throughout Illubabor and Western Wellega make a key contribution to the sustainable use of wetlands throughout the area. In those wetland-using communities where they are present and functional, empirical evidence suggests that wetland cultivation is not affecting the capacity of wetlands to continue to support agricultural activities, sedge production and natural functions, such as water storage. Although the repeated cultivation of wetlands has inevitably led to a decline in soil fertility and agricultural productivity in most areas, the complete degradation of wetlands to a dryland environment has largely been avoided, due mainly to locally developed management practices which are coordinated and regulated through WMIs.

Although most WMIs throughout the area are similar in terms of their objectives, structure and functioning, their evolution reflects sitespecific experiences of wetland management and varying degrees of intervention from external institutions. In Western Wellega, where there are indications that wetlands have been used for agriculture for over a century, WMIs have developed directly from similar institutions within the indigenous Oromo Gadaa system. In Illubabor, many WMIs have been established more recently through consultation with external institutions such as the Ministry of Agriculture.

This chapter has drawn particular attention to the relationship between WMIs and external institutions, in the context of a wider debate in the literature that considers whether such a relationship is beneficial or detrimental to the functioning of local institutions and their sustainability. In this respect, it is difficult to draw firm conclusions, since closer inspection of the history of many of the WMIs suggests that they have always operated in close contact with external institutions, whose influence has been spatially and temporally variable.

Moreover, the present situation is one where WMI members are actively pursuing stronger ties with external institutions for the enforcement of their own institutional arrangements. There is a danger, however, that in seeking support from external institutions, the WMIs will effectively hand over power and decision making to government structures renowned for their lack of sensitivity to local communities, and their deep suspicion of civil society groups. The main challenge for the future sustainability of the WMIs, and arguably wetland management itself, therefore, is achieving a level of external support which recognizes and values local knowledge, local decision making and social capital.

\section{Acknowledgements}

The research on which this chapter is based was achieved with the support of the UK Economic and Social Research Council (Grant Ref: RES000-22-0112). The authors are also grateful to Ato Afework Hailu and Ato Legesse Taffa for their assistance during the implementation of the research, and for their comments on this chapter.

\section{Endnote}

1 Although most women are actively involved in the collection of water and medicinal plants from wetlands, only the very few involved in wetland cultivation (those either widowed or divorced) are able to participate in the WMI.

\section{References}

Alemneh Dejene (1990) Environment, Famine and Politics in Ethiopia: a View From the Village. Lynne Reiner Publishers, Boulder, Colorado and London.

Agrawal, A. (2001) Common property institutions and sustainable governance of resources. World Development 29 (10), 1649-1672.

Bardhan, P. (1993) Symposium on management of local commons. Journal of Economic Perspectives 7 (4), 87-92.

Blunt, P. and Warren, D.M. (1996) Indigenous Organizations and Development. ITDG Publishing, London. 
Boserup, E. (1965) The Conditions of Agricultural Growth. Allen and Unwin, London.

Dixon, A.B. (2003) Indigenous Management of Wetlands: Experiences in Ethiopia. Ashgate, Aldershot, UK.

Dixon, A.B. (2005) Wetland sustainability and the evolution of indigenous knowledge in Ethiopia. The Geographical Journal 171 (4), 306-323.

Dugan, P.J. (1990) Wetland Conservation: a Review of Current Issues and Action. IUCN, Gland, Switzerland.

Ethiopia Network on Food Security (2001) Monthly report, 12 February 2001. http://www.fews.net/centers/ files/Ethiopia_200101en.pdf

Guri, B.Y. (2003) Indigenous institutions: potentials and questions. Compas Magazine 9, 16.

Hassen, M. (1990) The Oromo of Ethiopia: a History 1570-1860. Cambridge University Press, Cambridge, UK.

Hinchcliffe, F., Thompson, J., Pretty, J., Guijt, I. and Shah, P. (1999) Fertile Ground: the Impacts of Participatory Watershed Management. ITDG Publishing, London.

Howes, M. (1997) NGOs and development of local institutions: a Ugandan case-study. The Journal of Modern Africa Studies 35 (1), 17-35.

Hulme, D. and Woodhouse, P. (2000) Governance and the environment: policy and politics. In: Woodhouse, P., Bernstein, H. and Hulme, D. (eds) African Enclosures? The Social Dynamics of Wetlands in Drylands. James Currey, Oxford, UK, pp. 215-232.

Koku, J.E. and Gustafson, J.E. (2001) Local institutions and natural resource management in the South Tongu district of Ghana: a case study. Sustainable Development 11 (1), 17-35.

Leach, M., Mearns, R. and Scoones, I. (1999) Environmental entitlements: dynamics and institutions in community-based natural resource management. World Development 27 (2), 225-247.

Manig, W. (1999) Have societies developed indigenous institutions enabling sustainable resource utilization? Journal of Sustainable Agriculture 14 (4), 35-52.

Mazzucato, V. and Niemeijer, D. (2002) Population growth and environment in Africa: local informal institutions, the missing link. Economic Geography 78 (2), 171-193.

Ostrom, E. (1990) Governing the Commons: the Evolution of Institutions for Collective Action. Cambridge University Press, Cambridge, UK.

Pretty, J. and Ward, H. (2001) Social capital and the environment. World Development 29 (2), $209-227$.

Rasmussen, L.N. and Meinzen-Dick, R. (1995) Local Organisations for Natural Resource Management: Lessons from Theoretical and Empirical Literature. EPTD Discussion Paper No. 11, International Food Policy Research Institute, Washington, DC.

Richards, M. (1997) Common property resource institutions and forest management in Latin America. Development and Change 28, 95-117.

Shivakumar, S.J. (2003) The place of indigenous institutions in constitutional order. Constitutional Political Economy 14, 3-21.

Silvius, M.J., Oneka, M. and Verhagen, A. (2000) Wetlands: lifeline for people at the edge. Physical Chemistry of the Earth (B) 25 (7-8), 645-652.

Tafesse, A. (1996) Agro-ecological zones of south-west Ethiopia. MSc thesis, University of Trier, Germany.

Tiffen, M., Mortimore, M. and Gichuki, F. (1994) More People, Less Erosion: Environmental Recovery in Kenya. John Wiley, Chichester, UK.

Uphoff, N. (1992) Local Institutions and Participation for Sustainable Development. Gatekeeper Series No. 31, IIED, London.

Wade, R. (1988) Village Republics: Economic Conditions for Collective Action in South India. ICS Press, Oakland, California.

Warren, D.M., Slikkerveer, L.J. and Brokensha, D. (1995) The Cultural Dimension of Development: Indigenous Knowledge Systems. ITDG Publishing, London.

Watson, E. (2003) Examining the potential of indigenous institutions for development: a perspective from Borana, Ethiopia. Development and Change 34 (2), 287-309.

Wood, A.P. (1996). Wetland drainage and management in south-west Ethiopia: some environmental experiences of an NGO. In: Reenburg, A., Marcusen, H.S. and Nielsen, I. (eds) The Sahel Workshop 1996. Institute of Geography, University of Copenhagen, Copenhagen, pp. 119-136. 